\title{
A Survey of Tuition-Free English Major Students' Use of Language Learning Strategies
}

\author{
Jianfeng Zheng ${ }^{1}$ \\ ${ }^{1}$ School of Foreign Languages, Shanxi Normal University, Linfen, Shanxi, China \\ Correspondence: Zheng Jianfeng, School of Foreign Languages, Shanxi Normal University, 1 Gongyuan Street, \\ Yaodu District, Linfen, Shanxi, China. Tel: 134-5379-2029/86-357-205-1266. E-mail: lfzjfeng@126.com
}

$\begin{array}{lc}\text { Received: March 7, } 2013 & \text { Accepted: April 1, } 2013 \quad \text { Online Published: June 22, } 2013 \\ \text { doi:10.5539/ies.v6n7p9 } & \text { URL: http://dx.doi.org/10.5539/ies.v6n7p9 }\end{array}$

This research is sponsored by Shanxi Normal Univeristy as a teaching reform project "A Study of Tuition-free English Major Students' Use of Language Learning Strategies” (No. SD2013JGXM-23).

\begin{abstract}
In order to have a clear understanding of the differences between tuition-free students and non-tuition-free students in the strategies they employ and to prepare for the conduction of the Language Learning Strategy Course to the two groups of students, the author decided to conduct a survey as to the students' current use of language learning strategies. The instrument used in this study is a questionnaire designed by Wenden (1991). Besides the questionnaire, students' scores in the college entrance examination and the end-term exams are also collected for the sake of comparing their progress with the non-tuition-free students and with their performance before entering the university. Through analyzing the questionnaire and test results, the author has got the following findings: 1) In most courses, students in both classes have performed equally well. Only in listening, there exist some differences, which may indicate that tuition-free students are more capable of adjusting to college study and they are more able to deal with the new course of listening. 2) As to the strategy use of the two groups, there are some similarities between them due to the enduring influence of middle school teaching and examination system in China as they both pay more attention to language knowledge and skills. Their difference lies in the perception of their learning style and the ability to regulate their emotions.
\end{abstract}

Keywords: tuition-free students, non-tuition-free students, English major, language learning strategy

\section{Introduction}

As a nationwide policy, from 2007, students who have taken the College Entrance Examination and have reached the score limit of prestigious university enrollment requirements are entitled the opportunity to attend the six normal universities attached to the Ministry of Education in China without paying the tuition fee during the four-year college study on the condition that they should go to work in a primary or middle school in some remote or underdeveloped areas after graduation for a certain period of time. Unlike other college students, they are not allowed to take the postgraduate examination after graduation, but are given the chance to work for the master degree of education after three years of working. The purposes of this policy are to cultivate a group of excellent teachers and educators, to establish a thick atmosphere of respecting teachers and education and to encourage more and more young people to engage in teaching and make teaching their life-long career. This policy has attracted more and more middle school students, especially those from the countryside or poor families as this may help relieve the financial burden of the family and make it possible for such students to receive higher education and enjoy the best educational resources. In 2012, some provincial normal universities also got the qualification to admit the tuition-free students. In the university where the author is working, 500 middle school students are admitted as tuition-free students, among whom, 33 students are learning English out of their own choice. As the students are considered a different group of learners, the author is inspired to make a profound study as to their ways of managing their learning and life. They have both advantages and disadvantages over the rest of students at the university. Therefore, it is worthwhile to conduct the research. 


\section{Characteristics of Successful Learners}

Researches support the effectiveness of using L2 learning strategies and have shown that successful language learners often use strategies in an orchestrated fashion. Numerous researchers have started to investigate the strategies employed by those learners. The first studies in the good language learner tradition were made by Joan Rubin and David Stern, both of which were completed in 1975. Both of these studies proposed similar lists of strategies that good language learners use. On the basis of this, a large-scale study was performed at the Ontario Institute for Studies in Education (OISE) which investigated 34 language learners with good learning habits. This study found a list of six different strategies, which were similar to those proposed by Rubin and Stern:

1) Good language learners find an appropriate style of learning.

2) Good language learners involve themselves in the language-learning process.

3) Good language learners develop an awareness of language as both system and communication.

4) Good language learners pay constant attention to expanding their language knowledge.

5) Good language learners develop the second language as a separate system.

6) Good language learners take into account the demands that second language learning imposes.

In spite of the flurry of interest in the GLL in the mid to late 1970s, in the 1980s and 1990s, interest moved more in the direction of socio/cultural influences and individual differences as well as developing the concept of communicative competence into a communicative approach to language teaching. Seven years later, Griffiths, harking back to Joan Rubin's original title, published "Lessons from Good Language Learners." Whereas the early work in the GLL field had tended to emphasize the role of strategies, Griffiths' work took a broader view and presented the GLL as a highly complex involving many different variables, including motivation, age, style, personality, gender, meta-cognition, autonomy, beliefs, culture and aptitude. In addition, the target variables (including grammar, vocabulary, pronunciation, function and skills) and some of the situational factors (including method and error correction practices) which learners must manage if they are to be successful were discussed. Naiman, Frohlich, and Todesco(1975), Stem (1975), Naiman (1978), Ellis (1994), Rubin and Thompson(1982) and Wenden (1990)have summarized the strategies used by successful language learners, showing that they are more active learners, are more willing to take risks, pay more attention to form as well as to communication, seek opportunity to practice, are more able to monitor their learning progress and learn to think in the language and address the affective aspects of language acquisition. Ellis and Sinclair(1989) used a list of adjectives like self aware, inquisitive, tolerant, self critical, realistic, willing to experiment, actively involved and organized to decide whether a learner has the characteristics of a good language learner. Chamot and Kupper (1989) claimed that successful language learners tend to select strategies that work well together in a highly orchestrated way, tailored to the requirements of the language task. These learners can easily explain the strategies they use and why they employ them (O'Malley and Chamot, 1990). In China, Wen Qiufang(1996) made a case study to see in what aspect the successful learners and unsuccessful learners are different, concluding that it is the strategy use that results in the difference. The rationale for the studies is that there is more benefit from studying the habits of successful language learners than there is from studying learners who fossilize at an early stage or stop studying altogether. It was thought that if the strategies of successful learners could be found, then that knowledge could help learners who were not getting such good results.

\section{Research Design}

\subsection{Research Questions}

This research aims to address the following questions:

1) Do the tuition-free students exhibit any striking differences from the non-tuition-free students in terms of their language proficiency, their use of learning strategies and their satisfaction with their performance?

2) Do they possess the features of successful language learners?

3) Compared with their cognitive ability, do they also display outstanding capability in organizing their college life?

\subsection{Subjects}

The students admitted to School of Foreign Languages, Shanxi Normal University in Sept, 2012 were taken as the subjects. There were totally 73 students who were divided into two classes, with 33 students being the tuition-free students and the other 40 being the non-tuition-free students. It is worth mentioning that the non-tuition-free students majoring in English Education have also reached the score limit of prestigious 
universities. Therefore they can be considered to have the same starting point in terms of language proficiency. All the students in the tuition-free class are female while there are only 2 males in the other class. They are 20 years old on the average. The average scores of English in College Entrance Examination are 121.26 and 118.67 respectively, which further confirms that at the beginning of college study, they exhibited no significant difference. What's more, after they were admitted to the university, they have been taught all the subjects by the same teachers.

\subsection{Instruments}

As the students in both classes have all got a score equal to or above the score limit of prestigious universities, they can be considered to be above the average and can be viewed as the good language learners. Hence the questionnaire adopted in this research is borrowed from that designed by Wenden (1991), which is named "Questionnaire for a good language learner." The first part concerns the students' background information as to their names, genders, age, scores of college entrance examination and the names of the middle schools. The second part is composed of 20 items, fallen into seven categories, involving learning style, language knowledge and function, guessing and affective aspects(See Table 3.1). The questions are designed by Likert 5-point scale, ranging from 1 (meaning "This statement is never true to me") to 5 (meaning "This statement is always true to me"). Besides the 20 statements in the questionnaire, the students are asked some open-ended questions so that the author can get more detailed information concerning their assessment of their life and study. Also students' scores in Integrated Reading, Extensive Reading, Grammar and Writing, and Listening in the end-term exams are also collected for the sake of comparing their progress with the non-tuition-free students and with their performance before entering the university.

Table 3.1. Questionnaire classification

\begin{tabular}{ll}
\hline Categories of questions & items of questions \\
\hline Learning style & 1,2 \\
Active involvement & $3,4,5,6,7$ \\
Attention to language & $8,9,10$ \\
knowledge & \\
Focus on language & 11,12 \\
knowledge and skills & \\
Compensatory strategies & $13,14,15,16,17$ \\
L2 thinking & 18 \\
Affective strategy & 19,20 \\
\hline
\end{tabular}

\subsection{Procedures of the Study}

After one-term's study at the university, during which students were not given any guidance in language learning and management of their college life, the Language Learning Strategy Course was conducted in the second term. In the first class, students were required to respond to the questionnaire in about 50 minutes. Students were informed of the purpose of the study and asked to make the evaluation objectively without fearing that the evaluation may affect the teacher's impression of them. Both classes were included in the study, with the non-tuition-free students as a reference or a target of comparison. To learn the results of students' performance, their scores of the end-term examination in Integrated Reading, Extensive Reading, Grammar and Writing, and Listening were also collected and analyzed via Excel and SPSS 17.0.

\section{Data Analysis and Discussion}

\subsection{Analysis of the Scores in Both College-Entrance Examination and the End-Term Exams}

Table 4.1. Scores of English in college entrance examination

\begin{tabular}{lllll}
\hline & Max & Min & Average & No. \\
\hline TFC & 133 & 106 & 121.26 & 33 \\
NTFC & 133 & 103 & 118.67 & 40 \\
\hline
\end{tabular}


In Table 4.1, students' English scores in the College Entrance Examination are displayed. Of the total score of 150, the highest score in both classes is 133 and lowest scores are 106 in the tuition-free class (hereafter TFC) and 103 in the non-tuition-free class (hereafter NTFC). The average scores are 121.26 in TFC and 118.67 in NTFC. The mean difference is only 2.59 . So we can see that there is no significant difference between the two classes.

Table 4.2. Scores of the end-term examination

\begin{tabular}{lllll}
\hline classes /scores & $\begin{array}{l}\text { Integrated } \\
\text { Reading }\end{array}$ & $\begin{array}{l}\text { Extensive } \\
\text { Reading }\end{array}$ & $\begin{array}{l}\text { Grammar } \\
\text { \&Writing }\end{array}$ & Listening \\
\hline TFC & 80.242 & 85.394 & 83.303 & 69.394 \\
NTFC & 79.4125 & 85.303 & 82.15 & 63.925 \\
\hline
\end{tabular}

Table 4.2 shows the results of end-term examination in January, 2013. This is the first end-term examination for the freshmen. The total score of the four subjects are all 100. From the table, we can see that students' performance is quite satisfactory. Except in listening, there is no significant difference between the two groups in the other three subjects. Students in TFC did outperform students in NTFC, but the disparity is not very large. Only in listening, the difference is significant. The reasons can be that 1) most students have laid a solid foundation in reading and grammar due to the vast amount of practice in middle school in the context of examination-oriented education system. When they come to the university, what they have been exposed to in the Integrated Reading course and Extensive Reading course and Grammar and Writing course is still within their reach. 2)As the end-term examination is achievement test in nature, many of the test items are taken from the course books used in teaching, so through revision, students can master the knowledge they have learnt. The only striking phenomenon is the result of listening examination. As is shown in Table 4.2, in Listening course, students' scores in both classes are much lower than those in the other three subjects. This is also resulted from the regulation of the examination system. From 2005, in Shanxi Province, the College Entrance Examination in English did not include listening as a necessary part. Therefore, the teaching of listening was ignored in most middle schools. When students come to the university, they have to learn to listen from the very beginning. However, the teaching material is designed for college students who should have passed the Threshold level of English. This is also reflected in students' answers to the open-ended questions. Many students think that listening is the greatest trouble of university study and they admit that they cannot understand what the teacher is saying and do not know how to improve their listening in the short time.

Table 4.3. Maximum and minimum scores of the two classes in the end-term examination

\begin{tabular}{|c|c|c|c|c|}
\hline \multirow[t]{2}{*}{ Subject/Class } & \multicolumn{2}{|l|}{ TFC } & \multicolumn{2}{|l|}{ NTFC } \\
\hline & maximum & minimum & maximum & minimum \\
\hline $\begin{array}{l}\text { Integrated } \\
\text { Reading }\end{array}$ & 88 & 67 & 89 & 65 \\
\hline $\begin{array}{l}\text { Extensive } \\
\text { Reading }\end{array}$ & 90 & 75 & 91 & 69 \\
\hline $\begin{array}{l}\text { Grammar } \\
\& \text { Writing }\end{array}$ & 95.5 & 74 & 96 & 61 \\
\hline Listening & 93.5 & 48 & 81.5 & 35.5 \\
\hline
\end{tabular}

Although there is no significant difference in the examination results in the three subjects as is shown by the means of the two classes in Table 4.2, the score distribution can reveal the differences between the two classes. As is shown in Table 4.3, in all the subjects, the lowest scores appear in NTFC students with the disparity being more than 10 points. Especially in listening examination, students in TFC did much better than students in NTFC. The mean difference reaches 5.469. The highest score in TFC is 93.5 while that of NTFC is only 81.5. Similarly, the lowest scores of the two classes are 48 and 35.5, with the NTFC students doing much worse than the TFC students. 
Table 4.4. Range of TFC students' scores in the end-term examination (33 students)

\begin{tabular}{|c|c|c|c|c|c|c|c|c|c|}
\hline Subject/No. & $86--95$ & & $76--85$ & & $66--75$ & & $60-65$ & & Below 60 \\
\hline $\begin{array}{l}\text { Integrated } \\
\text { Reading }\end{array}$ & 6 & $18.2 \%$ & 17 & $51.5 \%$ & 10 & $30.3 \%$ & 0 & & 0 \\
\hline $\begin{array}{l}\text { Grammar } \\
\text { \&Writing }\end{array}$ & 9 & $27.3 \%$ & 23 & $69.7 \%$ & 1 & $3 \%$ & 0 & & 0 \\
\hline $\begin{array}{l}\text { Extensive } \\
\text { Reading }\end{array}$ & 18 & $54.5 \%$ & 13 & $39.4 \%$ & 2 & $6.1 \%$ & 0 & & 0 \\
\hline Listening & 2 & $6.1 \%$ & 3 & $9.1 \%$ & 17 & $51.5 \%$ & 9 & $27.3 \%$ & $6.1 \%$ \\
\hline
\end{tabular}

Table 4.5. Range of NTFC students' scores in the end-term examination (40 students)

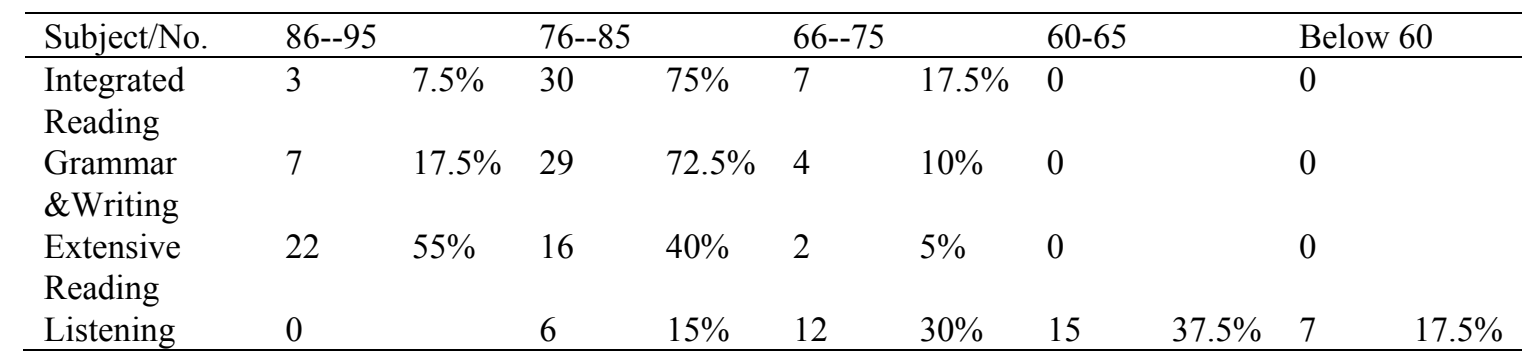

In Tables 4.4 and 4.5, the ranges of students' scores in all the subjects are displayed in terms of number and percentage. We may classify the ranges into excellent (86-95 and above), above average(76-85), average(65-75), passing(60-65) and failure (below 60). Then we can find that the excellent rate of the TFC students in all the subjects except Extensive Reading is higher than that of the NTFC students. In Extensive Reading course, the excellent rate is almost equal( $54.5 \%$ vs $55 \%)$. The NTFC students are gathered in the above average scale. In listening course, no students in NTFC has reached the excellent scale and the failing rate of the NTFC is much higher than that of the TFC students (17.5\% vs $6.1 \%)$. Hence it can be concluded that generally speaking, TFC students outperformed NTFC students in the end-term examination after more than three-month study.

\subsection{Analysis of the Questionnaire}

Table 4.6. Data of questionnaire

\begin{tabular}{llll}
\hline Items & Means of TFC & Means of NTFC & Differences \\
\hline 1 & 3.576 & 3.125 & 0.451 \\
2 & 4.333 & 4.125 & 0.208 \\
3 & 2.848 & 2.625 & 0.223 \\
4 & 3.219 & 2.75 & 0.469 \\
5 & 3.485 & 3.45 & 0.035 \\
6 & 3.313 & 3.775 & -0.462 \\
7 & 2.788 & 3.05 & -0.262 \\
8 & 4.061 & 3.925 & 0.136 \\
9 & 3.758 & 3.625 & 0.133 \\
10 & 3.818 & 3.875 & -0.057 \\
11 & 3.576 & 3.775 & -0.199 \\
12 & 3.631 & 3.825 & -0.194 \\
13 & 2.879 & 3.15 & -0.271 \\
14 & 4.061 & 3.6 & 0.461 \\
15 & 3.182 & 3.725 & -0.543 \\
16 & 3.394 & 3.4 & -0.006 \\
17 & 3.455 & 3.65 & -0.195 \\
18 & 3.167 & 3.25 & -0.083 \\
19 & 3.273 & 3.175 & 0.098 \\
20 & 3.394 & 3.25 & 0.144 \\
\hline
\end{tabular}


From Table 4.6, we may find that TFC students and NTFC students have something in common in selecting the strategies, i.e. they still prefer to use strategies that focus on language knowledge and language skills $(8,9,10,11,12)$. The means of these strategies have exceeded 3.5 scores, belonging to the frequently-used level. This suggests that they are still influenced by the traditional examination-oriented teaching. Besides this similarity, they have exhibited some differences. Among all the strategies, strategies 1, 4 and 14 are much preferred by students in TFC, which suggests that they have found a learning style that suits them; they will do better when they are familiar with the idea and they tend to guess when they have difficulties. It is also found that the NTFC students prefer to employ Items 6 and 15, which suggests that students in NTFC like cooperative learning and they try to find some ways to solve the problems. As for the least-frequently-used strategies, the TFC students rarely use Items 3,7 and 13 while the NTFC students rarely use items 3 and 4 . It is worth noting that students in both classes do not seek opportunity to learn English out of class, which may help explain the dependent nature of college students. Just like in middle school, they lack the autonomy to plan their own learning. They still expect the teacher to assign them some homework to do.

Table 4.7. Comparison of strategy use

\begin{tabular}{lll}
\hline Categories of questions & Means of TFC & Means of NTFC \\
\hline Learning style & 3.9545 & 3.625 \\
Active involvement & 3.1306 & 3.13 \\
Attention to language & 3.879 & 3.808 \\
knowledge & & \\
Focus on language knowledge & 3.6025 & 3.8 \\
and skills & & \\
Compensatory strategies & 3.3945 & 3.505 \\
L2 thinking & 3.167 & 3.25 \\
Affective strategy & 3.3335 & 3.2125 \\
\hline
\end{tabular}

When we put the data in the categories as proposed by Wenden, we may see that the means of all the categories of strategies have exceeded 3 points, with learning style, attention to language knowledge and focus on language knowledge and skill exceeding 3.5, which suggests that they can be regarded as good language learners as they both have met the criteria of good language learners and often use strategies to improve their own learning. In terms of learning style and affective regulation, the TFC students have exhibited greater control over their learning style and affections, which suggests that this group of learners have a clearer idea of themselves and their learning styles, so they are more able to choose the learning strategies that fit their learning style and learning goals. Although they may have made the same effort (3.1306 vs 3.13), the TFC students have achieved better results. On the other hand, students in NTFC just adopted the more mechanical and traditional techniques to try to improve their language knowledge and skills. This could possibly explain the differences in their performance in the listening examination.

\subsection{Analysis of the Open-Ended Questions}

In the third part of the questionnaire, the author has listed five questions concerning the differences between college life and middle school life, students' gains and troubles in the previous term, their arrangement of their time and energy, and their evaluation of their performance. The author has added the open-ended questions in order to supplement the objective questionnaire and get more detailed information about the subjects. It is also an opportunity for the author to see how students are able to evaluate themselves and what the relationship between their evaluation and proficiency is.

\subsubsection{Differences between College Life and Middle School Life}

Most students find that at university, they have more free time and they have to learn to arrange their life and study by themselves. Some students mention that life at university is more colorful. Besides learning the knowledge from the textbooks and the teachers, they have the chance to take part in some activities and they need to develop some social skills. There are some students who feel confused because they do not have a clear goal and have not learned to plan their learning. One student even mentions that college life calls for many 
abilities, including the ability to get along with others and the ability to solve problems by oneself. She also mentions that in college no one forces you to do anything. Everything depends on yourself.

\subsubsection{Greatest Trouble at University}

Most students admit that they have not tackled their college life successfully. They feel puzzled by the complexity of college life. Some students regard living on campus alone as the biggest trouble at college as they cannot deal with interpersonal affairs, which leads to their bad mood. Others are worried about the learning of so many subjects, especially listening, which gives students much trouble as they have not practiced it for at least three years in middle school. Thus they find it difficult to understand what the foreign teacher says and fail to perform well in the end-term exams. Still others think that they haven't found an effective way to study in college and do not know how to arrange the free time properly so as to find a balance between study and activities. Moreover, they cannot make good use of the library and other resources to help them learn.

\subsubsection{Organization}

Most students do not have a clear goal though some have very specific aims, like trying to be translator or a broadcaster; passing TEM Band 8; trying to improve listening or speaking; and learning English well. Some just say that their goal is to "learn as much as they can try" or "to be knowledgeable in English." More than one student simply says that they haven't any goals in college. They treated the question as a Yes/No question and responded by "No, I haven't." One student even set the goal as "relaxing herself," "studying harder" and "going shopping and playing in the free time."

When it comes to the issue of making timetable, only few students have formed the habit of making a weekly timetable and seriously followed it. Most students may have a rough plan in their minds, but would not take the trouble to note it down on paper, nor would they seriously follow it. Even though they know the importance of making the timetable, they find it difficult to follow it as there is always something to disturb their plans.

\subsubsection{Evaluation}

Students' responses to the question of evaluation are much simpler compared with their responses to other questions. Some students just use such words as "just so so," "quite perfect," "good," "OK", "not very good," "not bad" or "too bad". That is to say, their evaluation is quite vague and they have not mentioned in detail in what aspects they have performed satisfactorily and in what aspects they need to improve. In their responses to the question of evaluating themselves in the past term, none of them have mentioned that they have difficulty in learning listening although altogether 10 students failed this course and had got a score lower than 50 out of 100 . In other words, students have not realized their problems. In this way, we have reason to believe that it will be harder for them to make progress as they are unable to identify the problem areas in their college life.

\section{Conclusion}

Through the analysis of the questionnaire and the students' scores in the end-term examination, we can learn the current situation of strategy use by the students as well as their problems in tackling college life and study, which paves the way for the conduction of the Language Learning Strategy Course and gives us some insight into the guidance to the learners. We can also see the relationship between strategy use and students' performance and will try to cultivate the students' awareness of the learning process and help them become autonomous, independent and responsible learners. As this is just a prelude to the conduction of this course, more follow-up studies in forms of questionnaire, interview or case study will be done to explore the changes which will be produced on the learners.

\section{References}

Chamot, A. U., \& Kúpper, L. (1989). Learning strategies in foreign language instruction. Foreign Language Annals, 21(1), 13-24. http://dx.doi.org/10.1111/j.1944-9720.1989.tb03138.x

Ellis, \& Sinclair. (1989). Learning to learn English: Teacher's book. Cambridge: Cambridge University Press.

Ellis, R. (1994). The study of second language acquisition. Oxford: Oxford University Press.

Griffiths, C. (Ed.). (2008). Lessons from good language learners. Cambridge: Cambridge University Press. http://dx.doi.org/10.1017/CBO9780511497667

Naiman, N., Frohlich, M., Stern, H., \& Todesco, A. (1978). The good language learner. Education Series, 7. Toronto: Ontario Institute for Studies in Education.

O’Malley, J. M., \& Chamot, A. U. (1990). Learning strategies in second language acquisition. New York: Cambridge University Press. http://dx.doi.org/10.1017/CBO9781139524490 
Rubin, J. (1975). "What the "good language learner" can teach us. TESOL Quarterly, 9(1), 41-51. http://dx.doi.org/10.2307/3586011

Rubin, J., \& Thompson, I. (1982). How to be a more successful language learner. Boston: Heinle \& Heinle.

Stern, H. H. (1975). 'What can we learn from the good language learner?'. Canadian Modern Language Review, 31, 304-318.

Wen, Qiu-fang. (1996). On English learning strategies. Shanghai: Shanghai Foreign Language Education Press.

Wenden, A. L. (1990). Helping language learners think about learning. In Rossner, \& Bolitho (Eds.), Currents of change in English language teaching. Oxford University Press.

\section{Appendix: Questionnaire for a Good Language Learner}

Below is a simple questionnaire to help you think about what you do as a learner. Circle the answer that describe how you approach language learning.

Name: $\quad$ Age: Gender: male/female Score of English in CEE:

Middle School

1: never 2: rarely 3: sometimes 4: often 5: always

\section{The good language learner finds a style of learning that suits him/her}

1. 1 try to get something out of every learning situation even if I don't like it. 12345

2. I choose learning situations that are suited to my way of learning. 12345

\section{Good language learners are actively involved in the language learning process}

3. Besides language class, I plan activities that give me a chance to use and learn the language.

4. I choose activities because I am already familiar with the ideas. 12345

5. I can figure out my special problems. 12345

6. I try to do something about my special problems. 12345

7. I do things I don't usually do to gain more information about my foreign language. 12345

Good language learners try to figure out how the language works.

8. I pay special attention to pronunciation. 12345

9. I pay special attention to grammar. 12345

10. I pay special attention to vocabulary. 12345

\section{Good language learners know that language is used to communicate}

11. I try to develop good techniques to practise listening, speaking, reading and writing. 12345

12. I try to develop good techniques to improve my pronunciation, grammar and vocabulary. 12345

\section{Good language learners are like good detectives}

13. I am like a detective. I look for clues that will help me understand how language works 12345

14. When I don't know, I guess.

12345

15. I ask people to correct me if I make a mistake.

12345

16. I compare what I say with what others say to see if I'm using correct language. 12345

17. I think about what I've learned.

12345

Good language learners learn to think in the language 
18. I try to think in my target language. 12345

\section{Good language learners try to overcome their feelings of frustration and lack of confidence}

19. I overcome my feelings of frustration and lack of confidence.

\section{5}

20. I can laugh at my mistakes.

12345

Questions concerning your evaluation of yourself

1) What are the greatest differences between middle school life and college life?

2) Do your tackle your college life successfully? What is your greatest gain in the past semester of college life and what is your greatest trouble in adapting to college life?

3) At the beginning of the term, have you set a long-term goal as to how you decide to live the college life and what you decide to do after graduation?

4) Have you formed the habit of make a weekly timetable for the coming week last semester? If so, have you seriously followed the timetable and learned to check your performance?

5) What is your evaluation of your performance?

\section{Copyrights}

Copyright for this article is retained by the author(s), with first publication rights granted to the journal.

This is an open-access article distributed under the terms and conditions of the Creative Commons Attribution license (http://creativecommons.org/licenses/by/3.0/). 